\title{
Analisis Tingkat Kemiskinan di Propinsi NTT: Pendekatan Data Panel
}

\author{
Poverty Level Analysis in NTT Province: Panel Data Approach
}

\author{
Rosdianawaty Hatta ${ }^{1)}$, Rifki Khoirudin ${ }^{2)}$ \\ ${ }^{1,2)}$ Fakultas Ekonomi dan Bisnis, Universitas Ahmad Dahlan, Kota Yogyakarta \\ e-mail korespondensi: rifki.khoirudin@ep.uad.ac.id
}

\begin{abstract}
Info Artikel
Riwayat Artikel :

Diterima: 14 Januari 2020

Disetujui: 20 Februari 2020

Dipublikasikan: Juli 2020

Nomor DOI

10.33059/jseb.v11i2.2004

Cara Mensitasi :

Hatta, R. \& Khoirudin, R.

2020. Analisis Tingkat

Kemiskinan di Propinsi NTT:

Pendekatan Data Panel.

Jurnal Samudra Ekonomi

dan Bisnis. 11(2): 138-150.

Penelitian ini bertujuan untuk menganalisis pengaruh indeks pembangunan manusia, pengangguran, pertumbuhan ekonomi dan lama pendidikan terhadap tingkat kemiskinan penduduk di Propinsi NTT. Data sekunder yang digunakan berbentuk time series untuk periode 2011-2017 dan cross section untuk 22 kota/kabupaten NTT. Eviews 9 digunakan untuk menganalisis data panel tersebut. Hasil penelitian menunjukkan bahwa indeks pembangunan manusia berpengaruh negatif dan signifikan terhadap tingkat kemiskinan; tingkat pengangguran berpengaruh positif tetapi tidak signifikan terhadap tingkat kemiskinan; pertumbuhan ekonomi berpengaruh negatif namun tidak signifikan terhadap tingkat kemiskinan; dan, lama pendidikan berpengaruh positif dan signifikan terhadap tingkat kemiskinan. Secara simultan, keempat variabel independen memiliki pengaruh yang signifikan terhadap tingkat kemiskinan. Hasil koefisien determinasi menyatakan bahwa variabel-variabel independen yang digunakan memiliki kemampuan relatif besar dalam menjelaskan perubahan-perubahan yang terjadi atas tingkat kemiskinan penduduk di wilayah Propinsi NTT.
\end{abstract}

Kata Kunci: Kemiskinan Penduduk, Indeks Pembangunan Manusia, Pengangguran, Pertumbuhan Ekonomi, Lama Pendidikan.

\section{Article Info}

Article History :

Received: 14 January 2020

Accepted: 20 February 2020

Published: July 2020

\section{DOI Number :}

10.33059/jseb.v11i2.2004

How to cite :

Hatta, R. \& Khoirudin, R. 2020. Analisis Tingkat Kemiskinan di Propinsi NTT: Pendekatan Data Panel. Jurnal Samudra Ekonomi dan Bisnis. 11(2): 138-150.

\section{Abstract}

This study aims to analyze the effect of the human development index, unemployment, economic growth and duration of education on poverty rate of population in the Province of NTT. Secondary data used in the form of time series for the period 2011-2017 and cross sections for 22 city/regency of NTT. Eviews 9 is used to analyze the panel data. The results showed the human development index had a negative and significant effect on poverty rate; unemployment rate has a positive but unsignificant effect on poverty rate; economic growth has a negative but unsignificant effect on poverty rate; and, duration of education has a positive and significant effect on poverty rate. Simultaneously, the four independent variables have a significant effect on poverty. The determination analysis stated that the independent variables used have a relatively large ability to explain changes that occur in the poverty rate of the population in NTT Province.

Keywords: Poverty, Human Development Index, Unemployment, Economic Growth, Duration of Education. 


\section{PENDAHULUAN}

Di Indonesia, kemiskinan merupakan masalah yang sangat kompleks. Kemiskinan tidak hanya tejadi di satu kota saja, tetapi kemiskinan terjadi di beberapa daerah di setiap pulau. Secara umum, kemiskinan disebabkan karena kebutuhan manusia yang bermacam-macam. Adanya ketidaksamaan pola kepemilikan sumber daya yang menimbulkan pola distribusi pendapatan yang timpang. Hal ini menyebabkan penduduk miskin hanya memiliki sumberdaya alam dalam jumlah terbatas (Saidy \& Hidayah, 2018).

Kemiskinan merupakan masalah yang selalu hadir di setiap daerah yang sedang menjalani proses pembangunan. Adapun pembangunan sering kali terkena hambatan oleh beberapa faktor yang saling berkaitan, antara lain rendahnya penghasilan, penduduk yang tidak sedang dalam bekerja, level pendidikan serta derajat kesehatan yang kurang baik, infrastruktur yang tidak memadai, serta kurang sehatnya lingkungan sekitar (Pattimahu, 2016).

Secara jumlah absolut, penduduk miskin di wilayah Propinsi NTT pada bulan Maret 2018 sebanyak 1.142 .170 orang. NTT merupakan salah satu propinsi dengan persentase penduduk miskin yang sangat tinggi di negeri ini. Persentase penduduk miskinnya mencapai 21,35 persen dari jumlah total penduduk. Hal ini berarti sekitar seperlima penduduk yang ada di NTT termasuk dalam kategori penduduk miskin.

Kesadaran atas kemiskinan akan dirasakan ketika dilakukan pembandingan kehidupan yang sedang dijalani seorang individu saat ini dengan kehidupan orang lain yang tergolong mempunyai tingkat kehidupan ekonomi yang lebih tinggi. Hal ini bisa menyulitkan pemerintah ketika akan menentukan penduduk miskin, karena mereka (penduduk) sendiri tidak sadar akan kondsi kemiskinannya (Nurwati, 2008).

Indeks Pembangunan Manusia atau IPM merupakan alat ukur untuk melihat keadaan pembangunan di masa mendatang. Indeks tersebut juga dapat memperediksi kemajuan pembangunan manusia untuk kedepannya. Ada dua kriteria yang perlu disorot dalam pembanguan, yaitu kecepatan dan status pencapaian.

Pengangguran juga merupakan salah satu indikator penyebab terjadinya kondisi kemiskinan di suatu daerah; dan upaya untuk menurunkan tingkat pengangguran dan kemiskinan adalah sama pentingnya. Secara teori, jika masyarakat tidak menganggur berarti mereka mempunyai pekerjaan dan penghasilan, dan dengan penghasilan yang dimiliki dari bekerja diharapkan dapat memenuhi kebutuhan hidup. Jika kebutuhan hidup terpenuhi maka masyakat tidak akan mengalami kekurangan, sehingga dapat menurunkan tingkat kemiskinan. Dengan pemikiran itu, tingkat pengangguran yang rendah (kesempatan kerja tinggi) maka kemiskinan juga akan rendah (Yarlina, 2012).

Pertumbuhan ekonomi dipandangsangat diperlukan oleh setiap negara guna untuk membangun kesejahteraan rakyat. Jika pertumbuhan ekonomi di suatu negara baik maka tingkat kesejahteraan rakyat akan baik juga. Akan tetapi, pertumbuhan ekonomi bukan hanya salah satu faktor penyebab terjadinya kemiskinan.

Faktor selanjutnya adalah lama durasi pendidikan. Pendidikan merupakan salah satu bentuk modal manusia yang menunjukkan kualitas sumber daya manusia. Pendekatan modal manusia berfokus pada kemampuan manusia guna untuk meningkatkan utilitas dengan meningkatkan pendapatan. Adanya pendidikan yang memadai membantu mereka mendapatkan pekerjaan yang lebih baik dan mendapatkan upah yang cukup untuk 
memenuhi kebutuhan sehari-hari bagi diri mereka dan keluarganya (Nailatussa'adah, 2019).

Pada dasarnya level kemiskinan yang senantiasa diidentifikasikan dengan taraf hidup yang rendah, dapat diartikan sebagai suatu keadaan dimana penghidupan penduduk ditandai oleh adanya serba kekurangan akan kebutuhan pokok (Sartika et al., 2016). Pembangunan manusia adalah proses untuk memilih, memilih untuk bisa berkembang dan sehat, dan berilmu serta berpendidikan yang tinggi. Tujuannya tidak lain yaitu untuk memenhi hidup secara layak (Dewi et al., 2017).

Pengangguran bukan sekedar hanya masalah bagi yang tidak memiliki pekerjaan, tapi masalah bagi kita semua. Jika masyarakat tidak memiliki penghasilan untuk membeli kebutuhan sehari-hari maka perusahaan tidak akan memperoleh pemasukan dana untuk usahanya. Dampaknya akan mempengaruhi aktivitas perekonomian di suatu daerah (Swaramarinda, 2014).

Terkait dengan latar belakang yang telah diuraikan, topik permasalahan yang dibahas dalam penelitian ini adalah bagaimana pengaruh indeks pembangunan manusia, tingkat pengangguran, tingkat pertumbuhan ekonomi, dan lama pendidikan terhadap tingkat kemiskinan di Provinsi NTT.

\section{Indeks Pembangunan Manusia (IPM)}

Kata-kata sambutan di dalam human development report (HDR) yang pertama kali dipublikasikan oleh UNDP pada tahun 1990 menekankan betapa pentingnya pembangunan pada manusia yang dimana setiap orang adalah tujuan akhir dan bukan sebagai alat pembangunan. Pembangunan manusia adalah proses untuk memilih, memilih untuk bisa berkembang dan sehat, dan berilmu serta berpendidikan yang tinggi. Tujuannya tidak lain yaitu untuk memenuhi penghidupan secara layak (Dewi et al., 2017).

Untuk mengukur IPM diperlukan empat komponen, yaitu angka harapan hidup yang di ukur dalam keberhasilan suatu capaian kesehatan; angka melek huruf dan rata-rata lama sekolah yang diukur melalui tingkat keberhasilan seseorang di dalam bidang pendidikan; serta, kemampuan seseorang dalam memenuhi kebutuhan sehari-hari yang dapat dilihat dari besarnya pengeluaran perkapita sebagai pendekatan pendapatan yang mengukur keberhasilan seseorang dalam bidang pembangunan layak hidup (Alhudhori, 2017).

Berdasarkan uraian hubungan tersebut, maka dinyatakan hipotesis pertama dalam penelitian ini adalah:

H1: Indeks pembangunan manusia (IPM) berpengaruh negatif terhadap tingkat kemiskinan.

\section{Pengangguran}

Pengangguran merupakan masalah yang sangat kompleks dan secara langsung dapat mempengaruhi manusia. Ketikaa seseorang kehilangan sebuah pekerjaan maka dapat di artikan bahwa standar hidup mereka juga akan menurun dan mereka akan mendapat tekanan psikologis. Oleh karena itu, masalah pengangguran sudah tidak asing lagi bagi kita, sebab pengangguran sudah menjadi trending topik disetiap daerah dan juga menjadi salah satu perdebatan politik dan politisi. Keduanya sering mengklim bahwa kebijakan yang mereka tawarkan adalah akan membantu menciptakan lapangan kerja (Mankiw, 2006).

Arsyad (1997) menyatakan bahwa pengangguan dan kemiskinan memiliki keterkaitan antar satu sama lain. Untuk sebaigian masyarakat yang tidak memiliki pekerjaan full-time maupun part-time, maka mereka dikategorikan kelompok miskin; sedangkan yang mempunyai pekerjaan yang 
penuh bisa dikatakan orang yang kaya. Karena kadangkala seseorang ingin memcari pekerjaan dengan gaji tinggi, akan tetapi kemampuan yang mereka miliki tidak seseuai dengan posisinya. Ketika seseorang memiliki pekerjaan maka kemakmuran seseorang akan meningkat; tetapi sebaliknya, jika seseorang tidak mempunyai pekerjaan maka tingkat kemakmuran seseorang akan mengalami penurunan (Susanto et al., 2017).

Berdasarkan uraian hubungan yang telah dijelaskan, maka hipotesis kedua dalam penelitian ini adalah:

H2: Tingkat pengangguran berpengaruh positif terhadap tingkat kemiskinan.

\section{Pertumbuhan Ekonomi}

Siregar dan Wahyuniarti (2008) memberikan pernyataan bahwa pertumbuhan ekonomi sangat penting untuk sebuah wilayah, terlebih lagi untuk pengurangan kemiskinan. Pertumbuhan yang efektif dapat mengurangi kemiskinan. Artinya, pemerataan pendapatan juga sangat perlu diterapkan di berbagai wilayah guna untuk pemerataan kesejateraan (Suryandari, 2017).

Kuznet, seperti dirujuk oleh Tambunan, (2014) menyatakan bahwa terdapat hubungan antara pertumbuhan ekonomi dengan level kemiskinan. Pada posisi awal pertumbuhan ekonomi mempertinggi tingkat kemiskinan cenderung meningkat; tapi saat tahap berikutnya terjadinya penurunan kemiskinan secara perlahan. Atau ada pengaruh negatif antara pertumbuhan ekonomi dengan kemiskinan.

Berdasarkan alur hubungan yang telah diuraikan tersebut, maka dinyatakan hipotesis ketiga dalam penelitian ini yaitu:

H3: Pertumbuhan ekonomi berpengaruh negatif terhadap tingkat kemiskinan.

\section{Tingkat Pendidikan}

Pendidikan merupakan proses untuk mengembangkan suatu pemikiran seseorang melalui belejar di sekolah atau perguruan tinggi. Pendidikan mempunyai peran yang besar bagi pembangunan di suatu negara. Di dalam Undang-Undang Dasar 1945 pasal 27 dinyatakan bahwa pendidikan sebagai penyiapan warga negara yang baik, yakni warga negara yang mengetahui hak dan kewajibannya.

Korelasi antara pendidikan dan kemiskinan sudah lama menjadi isu sentral di banyak negara, baik negara maju maupun berkembang. Bahkan di negara maju seperti Amerika serikat, permasalahan muncul sebagai akibat besarnya subsidi yang diperuntukkan bagi kelompok masyarakat miskin. Sedangkan di Indonesia, letak permasalahannya yaitu terjadinya ketidak adilan dalam memperoleh akses pendidikan antara si kaya dan si miskin. Yaitu, biaya yang harus dikeluarkan untuk sekolah bagi si kaya dan si miskin relatif sama tanpa melihat latar belakang ekonomi keluarganya (Jundi, 2014).

Berdasarkan alur hubungan yang telah diuraikan tersebut, maka dinyatakan hipotesis keempat dalam penelitian ini yaitu:

H4: Lama pendidikan berpengaruh negatif terhadap tingkat kemiskinan.

\section{METODE PENELITIAN}

Penelitian mengenai pengaruh variabelvariabel Indeks Pembangunan Manusia (IPM), tingkat pengangguran (P), pertumbuhan ekonomi (PE), serta lama pendidikan (PD) terhadap tingkat kemiskinan (KM) dari penduduk, menggunakan data time series selama enam tahun yang diwakili data tahunan dari 2012-2017 dan data cross section sebanyak 22 kabupaten/kota pada Provinsi NTT.

Model fungsi yang akan digunakan untuk mengetahui tingkat kemiskinan di Provinsi NTT yaitu: 
$\mathrm{KM}=\mathrm{f}(\mathrm{IPM}, \mathrm{TP}, \mathrm{PE}, \mathrm{PD})$

$\mathrm{KM}=\beta_{0}+\beta_{1} \mathrm{IPM}+\beta_{2} \mathrm{TP}+\beta_{3} \mathrm{PE}+\beta_{4} \mathrm{PD}+E_{i t}$

dimana KM adalah tingkat kemiskinan dari penduduk; IPM adalah Indeks Pembangunan Manusia; TP adalah tingkat pengangguran; PE adalah pertumbuhan ekonomi; PD adalah lama pendidikan; $i$ adalah pola cross section; $t$ adalah pola time series; $\beta_{0}$ adalah konstanta; $\beta_{1}$ sampai $\beta_{4}$ adalah koefisien regresi; dan, $E$ adalah error.

\section{Analisis Metode Data Panel}

Metode analisis dalam penelitian ini menggunakan data panel sebagai instrumen olah data. Analisis data panel tediri dari gabungan antara data deret-waktu (time-series data) dan data kerat-lintang (cross section data).

Analisis data panel yang digunakan untuk penelitian ini mempunyai beberapa keunggulan. Pertama, analisis ini dapat memberikan jumlah pengamatan yang besar, meningkatkan degress of freedom (derajat kebebasan), dan variablilitas yang besar dan juga dapat mengurangi kolinearitas antara variabel penjelas, sehingga akan menghasilkan ekonometrik yang efisien. Keunggulan kedua bahwa data panel lebih informasif, lebih bervariasi, yang hanya dapat diberikan oleh data cross-section dan time-series saja.

Dalam data panel, unit cross-section yang sama di survei dalam beberapa waktu. Dalam persamaan model, data panel yang menggunakan data cross section dapat ditulis sebagai berikut:

$\mathrm{Y}_{\mathrm{j}}=\beta_{\mathrm{o}}+\beta_{1} X_{\mathrm{i}}+\varepsilon_{\mathrm{j}}: \mathrm{i}=1,2, \ldots, \mathrm{N}$

dimana $\mathrm{N}$ adalah banyaknya data crosssection.

Sedangkan persamaan model yang menggunakan data time-series adalah:

$\mathrm{Y}_{\mathrm{j}}=\beta_{\mathrm{o}}+\beta_{1} X_{\mathrm{i}}+\varepsilon_{\mathrm{t}}: \mathrm{t}=1,2, \ldots, \mathrm{N}$ dimana $t$ diartikan sebagai seberapa banyak data time-series.

Berikut ini adalah persamaan model antara time series dan cross section:

$Y_{j t}=\beta_{0}+\beta_{1} X_{j}+\varepsilon_{j t}$

$(\mathrm{i}=1,2, \ldots),(\mathrm{N} ; \mathrm{t}=1,2, \ldots, \mathrm{T})$

dimana $\mathrm{N}$ adalah observasi; $\mathrm{T}$ adalah waktu; dan, $(\mathrm{N} x \mathrm{~T})$ adalah data panel.

Untuk menganalisis data panel, kita perlu memasukan tiga model pendekatan. Tiga model tersebut berupa common effect, fixed effect, dan random effect. Untuk lebih jelasnya, pada bagian berikutnya diberikan penjelasan mengenai ketiga model tersebut:

\section{Pendekatan Efek Tetap (Fixed Effect)}

Fixed effect dalam hal ini adalah bahwa satu object yang memiliki nilai konstan yang tetap besarnya untuk berbagai periode waktu. Demikian pula halnya dengan koefisien regresi yang memiliki besaran yang tetap dari waktu ke waktu (Risno, 2017).

\section{Pendekatan Efek Acak (Random Effect)}

Pendekatan efek acak atau random effect dilakukan untuk memperbaiki kondisi inefisiensi proses least square dengan memperthitungkan error serta cross-section dan time-series. Model random effect adalah variasi dari estimasi generalized least squares (Prasetio, 2018). Persamaan dari Random Effect Model adalah:

$Y_{i t}=\beta_{0}+\beta_{1} X_{i t}+\varepsilon_{\mathrm{j}}+u_{\mathrm{jt}}$

$Y_{i t}=\beta_{0}+\beta_{1} X_{j t}+W_{i t}$

Persamaan tersebut adalah korelasi error term $\left(W_{\mathrm{jt}}\right)$ terhadap rumus di atas korelasi tersebut yang terdiri dari $\varepsilon_{\mathrm{j}}+\mathrm{u}_{\mathrm{it}}$. Dari setiap komponen error tersebut tidak saling berkaitan satu sama lain antara crosssection maupun time-series. Yang disebut 
Error term adalah homoskedastik (Nugroho, 2012).

\section{Metode Common Effect}

Pada dasarnya, pooled least square model merupakan metode yang meminimumkan jumlah error kuadrat sama seperti OLS. Tetapi, data yang digunakan bukan data timeseries atau cross-section saja, melainkan data panel yang diterapkan dalam bentuk pooled (Astuti, 2017). Persamaan model PLS yang digunakan adalah:

$\mathrm{Y}_{\mathrm{jt}}=\alpha+\beta \mathrm{X}_{\mathrm{jt}}+\mathrm{u}_{\mathrm{jt}}$

$i=1, \ldots, \mathrm{N} \quad$ dan $\quad t=1, \ldots, \mathrm{K}$

$\mathrm{N}$ mengartikan bahwa bagian dari crosssection secara individu; sedangkan $t$ adalah banyaknya time-series. Proses common effect dilakukan dengan cara menyatukan data dari cross-section dan time-series serta akan memberikan hasil jumlah observasi sebanyak NT (Nugroho, 2012).

\section{Uji Chow}

Spesifikasi uji model ini dengan tujuan untuk menentukan model analisis data panel yang akan digunakan. Uji yang pertama dilakukan adalah dengan menggunakan Uji Chow (Chow test). Uji Chow digunakan untuk menentukan model mana yang sebaiknya digunakan bagi penelitian ini. Pemilihan model jika model memilih:

$\mathrm{H}_{0}$ : Memilih model Common Effect

$\mathrm{H}_{a}$ : Memilih model Fixed Effect

Apabila hasil uji menunjukkan nilai probabilitas dibawah 0,05 maka akan dipilih model fixed effect. Akan tetapi, jika hasil pengolahan menunjukkan nilai probabilitas di atas 0,05 maka akan dipilih model common effect. Setelah uji chow dilakukan dan apabila uji ini memilih fixed effect, maka perlu dilakukan Uji Hausman (Hausman Test).

\section{Uji Hausman}

Uji Hausman dilakukan untuk tujuan mengetahui apakah hasil uji menunjukkan fixed effect atau random effect. Penilaian uji hausman yang digunakan apabila hasil menunjukkan:

$\mathrm{H}_{0}$ : Memilih Random Effect model

$\mathrm{H}_{a}$ : Memilih Fixed Effect model

Dari hipotesis tersebut bisa dikatakan bahwa jika hasil uji Hausman adalah Ho diterima dan nilai probabilitas kurang dari 5\% $(0,05)$ maka pemilihan model tertuju kepada fixed effect. Sebaliknya, jika hasil uji menunjukkan angka di atas nilai probabilitas 5\% maka dipilih model random effect (Irawan, 2017).

\section{Uji Parsial (Uji t)}

Uji t dilakukan untuk menguji variabelvariabel independen secara parsial dengan cara statistik, dan ingin mengetahui apakah nilai probabilitas atau Sig. $t$ lebih kecil atau lebih besar dari $\alpha(0,05)$. Apabila nilai Sig. $t$ lebih kecil dari $\alpha$ berarti variabel independen secara parsial memiliki pengaruh yang signifikan terhadap variabel dependen. Sebaliknya, apabila nilai Sig. $t$ lebih besar dari $\alpha$ berarti variabel independen secara parsial tidak memiliki pengaruh yang signifikan terhadap variabel dependen.

\section{Uji Simultan (Uji F)}

Uji F dilakukan untuk menguji semua variabel independen dengan cara statistik, dan ingin mengetahui apakah nilai probabilitas atau Sig. F lebih kecil atau lebih besar dari $\alpha$ $(0,05)$. Apabila nilai Sig. F lebih kecil dari $\alpha$ berarti variabel-variabel independen secara simultan memiliki pengaruh yang signifikan terhadap variabel dependen. Sebaliknya, apabila nilai Sig. F lebih besar dari $\alpha$ berarti variabel-variabel independen secara simultan 
tidak memiliki pengaruh yang signifikan terhadap variabel dependen.

\section{Koefisien Determinasi $\left(\mathbf{R}^{2}\right)$}

Hasil determinasi koefisien ini bertujuan untuk melihat besarnya persentase varian atau keragamana variabel dependen yang dapat dijelaskan oleh variabel independen dalam model. Nilai dari koefisien determinasi berkisar dari angka nol (0) sampai satu (1). Apabila nilai determinasi koefisien mendekati angka satu (1), maka model dikatakan semakin baik karena menunjukkan semakin tepat atau cocoknya suatu garis regresi, serta semakin besar variasi variabel independen dapat menjelaskan variabel dependen, (Surayya, 2018).

\section{HASIL ANALISIS \\ Hasil Pemilihan Model}

Pada bagian ini dilakukan pengujian untuk menentukan model manakah yang digunakan dalam penelitian, yaitu antara fixed effect, random effect atau common effect. Mula-mula akan dilakukan uji Chow, dan dilanjutkan dengan uji Hausman.

Tabel 1. Hasil Uji Chow

\begin{tabular}{lrrr}
\hline \multicolumn{1}{c}{ Effects Test } & \multicolumn{1}{c}{ Statistic } & \multicolumn{1}{c}{ df } & \multicolumn{1}{c}{ Prob. } \\
\hline Cross-section F & 6.096674 & $(21,128)$ & 0.0000 \\
Cross-section Chi-square & 106.762804 & 21 & 0.0000 \\
\hline
\end{tabular}

Sumber: Data primer diolah, 2019.

Tabel 2. Hasil Uji Hausman

\begin{tabular}{rrrr}
\hline Test Summary & Chi-Sq. Statistic & Chi-Sq. df & \multicolumn{1}{c}{ Prob. } \\
\hline Cross-section random & 98.352434 & 4 & 0.0000 \\
\hline
\end{tabular}

Sumber: Data primer diolah, 2019.

Berdasarkan hasil uji chow pada Tabel 1 dengan redundant test, diperoleh nilai probabilitas chi-square sebesar 0,0000. Dari hasil tersebut didentifikasi bahwa setiap model yang ada menunjukkan nilai dibawah $\alpha$ $(0,05)$. Dengan demikian, berdasarkan hasil uji Chow dinyatakan bahwa fixed effect model adalah model yang terpilih untuk digunakan dalam penelitian ini.

Uji selanjutnya yang dilakukan adalah uji Hausman yang bertujuan untuk menentukan apakah hasil uji nantinya memilih model fixed effect atau random effect. Berdasarkan Tabel 2 diperoleh nilai probabilitas chi-square sebesar 0,0000 atau lebih kecil dari $\alpha(0,05)$. Dengan demikian, berdasarkan hasil uji Hausman juga dinyatakan bahwa model yang terpilih untuk digunakan dalam penelitian ini adalah fixed effect.

\section{Hasil Fixed Effect Model}

Pada bagian ini dilakukan pengujian regresi atas data panel yang digunakan untuk penelitian ini. Hasil pengolahan untuk fixed effect model ditunjukkan dalam Tabel 3.

Berdasarkan hasil-hasil yang ditunjukkan dalam Tabel 3 bisa diidentifikasikan IPM $\left(X_{1}=-17,58937\right)$ serta pertumbuhan ekonomi $\left(X_{3}=-0,300929\right)$ memiliki pengaruh dengan arah yang negatif atas tingkat kemiskinan. Artinya, apabila IPM ataupun pertumbuhan ekonomi mampu ditingkatkan maka akan menurunkan tingkat kemiskinan; sebaliknya, apabila IPM atau pertumbuhan ekonomi 
mengalami penurunaan maka tingkat kemiskinan dapat mengalami peningkatan.

Di sisi lain, hasil dalam Tabel 3 menunjukkan bahwa tingkat pengangguran $\left(\mathrm{X}_{2}=1,877645\right)$ serta lama pendidikan $\left(\mathrm{X}_{4}=\right.$ 100,5063) memiliki pengaruh dengan arah yang positif terhadap tingkat kemiskinan. Artinya, apabila tingkat pengangguran atau durasi waktu atau lama pendidikan yang mampu diselesaikan seorang individu mengalami peningkatan maka mempertinggi tingkat kemiskinan; sebaliknya, apabila tingkat pengangguran ataupun durasi waktu ataupun lama pendidikan yang mampu diselesaikan individu yang bersangkutan mengalami penurunan maka tingkat kemiskinan juga bisa mengalami penurunan.

Tabel 3. Hasil Fixed Effect Model

\begin{tabular}{crrrr}
\hline Variable & \multicolumn{1}{c}{ Coefficient } & \multicolumn{1}{c}{ Std. Error } & \multicolumn{1}{c}{ t-Statistic } & \multicolumn{1}{c}{ Prob. } \\
\hline C & 120.7730 & 33.00989 & 3.658691 & 0.0004 \\
X1 & -17.58937 & 2.546221 & -6.908027 & 0.0000 \\
X2 & 1.877645 & 1.513502 & 1.240596 & 0.2170 \\
X3 & -0.300929 & 5.752181 & -0.052316 & 0.9584 \\
X4 & 100.5063 & 11.54769 & 8.703585 & 0.0000 \\
\hline
\end{tabular}

\begin{tabular}{cr} 
Fixed Effects (Cross) & \\
KSB-C & -6.828131 \\
KST-C & -63.35512 \\
KK-C & 107.1586 \\
KTTS-C & -55.97401 \\
KTTU-C & -94.10242 \\
KB-C & 44.56429 \\
KA-C & 5.211164 \\
KL-C & 73.78768 \\
KFT-C & 1.976164 \\
KS-C & 50.32721 \\
KE-C & -41.16166 \\
KN-C & 85.60965 \\
KM-C & -131.0620 \\
KRN-C & -87.26783 \\
KMB-C & 153.3303 \\
KST-C & -63.35512 \\
KSBD-C & -7.124323 \\
KN-C & 85.60965 \\
KMT-C & 96.33777 \\
KSR-C & -129.7784 \\
KM-C & -131.0620 \\
KK-C & 107.1586 \\
Adjusted R-squared & 0.822862 \\
\hline
\end{tabular}

Sumber: Data primer diolah, 2019. 
Tabel 4. Hasil Uji Simultan

\begin{tabular}{lrr}
\hline \multicolumn{1}{c}{ Variable } & F-Statistic & Prob. \\
\hline $\operatorname{IPM}\left(\mathrm{X}_{1}\right)$ & & \\
$\operatorname{TP}\left(\mathrm{X}_{2}\right)$ & 23.78402 & 0.0000 \\
$\operatorname{PE}\left(\mathrm{X}_{3}\right)$ & & \\
$\mathrm{LP}\left(\mathrm{X}_{4}\right)$ & & \\
\hline
\end{tabular}

Sumber: Data primer diolah, 2019.

\section{Hasil Uji Parsial}

Tabel 3 juga menunjukkan hasil uji parsial atau Uji $\mathrm{t}$ (t-test) terkait derajat signifikansi atas pengaruh dari masingmasing variabel independen terhadap variabel dependen.

Berdasarkan hasil pengolahan data panel menggunakan fixed effect model diperoleh bahwa nilai Sig. $\mathrm{t}$ untuk IPM $\left(\mathrm{X}_{1}=\right.$ $0,0000)$ serta lama pendidikan $\left(\mathrm{X}_{4}=0,0000\right)$ adalah lebih kecil dari $\alpha$ atau 0,05 . Dengan demikian bisa dinyatakan bahwa IPM serta lama pendidikan merupakan variabel-variabel independen yang memiliki pengaruh parsial secara signifikan terhadap tingkat kemiskinan di Propinsi NTT.

Sebaliknya, hasil fixed effect model menunjukkan bahwa nilai Sig. $t$ untuk tingkat pengangguran $\left(X_{2}=0,2170\right)$ serta pertumbuhan ekonomi $\left(\mathrm{X}_{3}=0,9584\right)$ adalah lebih besar dari $\alpha$ atau 0,05 . Dengan demikian bisa dinyatakan bahwa tingkat pengangguran serta pertumbuhan ekonomi merupakan variabelvariabel independen yang memilki pengaruh parsial secara tidak signifikan terhadap tingkat kemiskinan di Propinsi NTT.

\section{Hasil Uji Simultan}

Tabel 4 menunjukkan hasil uji simultan atau Uji F (F-test) terkait derajat signifikansi atas pengaruh dari keempat variabel independen secara bersama-sama terhadap variabel dependen.

Berdasarkan Tabel 4 maka dinyatakan bahwa hasil pengolahan data panel meng- gunakan fixed effect model diperoleh nilai Sig. F sebesar 0,0000 adalah lebih kecil dari $\alpha$ atau 0,05 . Dengan demikian bisa dinyatakan bahwa IPM, tingkat pengangguran, pertumbuhan ekonomi serta lama pendidikan memiliki pengaruh simultan yang signifikan terhadap tingkat kemiskinan di Propinsi NTT.

\section{Hasil Koefisien Determinasi}

Koefisien determinasi menyatakan derajat kemampuan dari variabel-variabel independen yang dicakup dalam model penelitian mampu menjelaskan perubahanperubahan yang dialami variabel dependen. Nilai koefisien determinasi yang diperoleh pada penelitian ini ditunjukkan di dalam Tabel 3.

Berdasarkan hasil $R$-Squared pada Tabel 3 sebesar 0,822862 maka dinyatakan IPM, tingkat pengangguran, pertumbuhan ekonomi dan lama pendidikan, sebagai variabel-variabel independen dalam model penelitian ini mampu menjelaskan perubahanperubahan yang terjadi pada tingkat kemiskinan dari penduduk di Propinsi NTT sebesar $82,29 \%$ atau relatif besar. Namun demikian, hasil koefisien determinasi tersebut juga mengindikasikan masih adanya variabelvariabel independen lain yang tidak tercakup dalam model penelitian namun mampu menjelaskan atau mempengaruhi variasi dari tingkat kemiskinan pada lokasi penelitian, yaitu sebesar $17,71 \%$. 


\section{Pembahasan}

Hasil penelitian menunjukkan bahwa IPM memiliki pengaruh negatif dan signifikan terhadap tingkat kemiskinan di provinsi NTT. Hal ini berarti bahwa IPM pada suatu wilayah yang semakin baik atau tidak baik akan menunjukkan kualitas SDM yang baik sehingga mampu mengurangi angka kemiskinan di suatu daerah tersebut. Mengukur IPM dapat dilakukan dengan melihat pembangunan manusia berdasarkan dari ilmu pendidikan yang didapat dan melek huruf, kesehatan yang terjamin dan umur yang panjang, serta jumlah pendapatan yang mampu memenuhi hidupnya (Zuhdiyaty \& Kaluge, 2017). Apabila kesehatan dapat terjamin serta pendapatan yang cukup maka masyarakat mampu memenuhi kebutuhan hidupnya.

Berdasarkan hasil penelitian diketahui juga bahwa tingkat pengangguran memiliki pengaruh positif dan tidak signifikan terhadap tingkat kemiskinan di Provinsi NTT. Hal ini karena naik turunnya tingkat pengangguran tidak berdampak pada tinggi rendahnya tingkat kemiskinan (Amalia, 2012). Hal ini dikarenakan kecukupan penghasilan keluarga akan mampu memenuhi kehidupan keluarga yang belum bekerja. Mereka hanya akan mendaftarkan diri pada perusahaan yang sesuai dengan keahlian yang ada atau bisa saja penghasilan yang diinginkan (Aldino, 2018). Alasan lainnya adalah mengapa tingkat pengangguran tidak berpengaruh terhadap kemiskinan karena pengangguran menurun sejak sepuluh tahun terakhir.

Pertumbuhan ekonomi yang dilihat dari PDRB di Provinsi NTT diperoleh tidak berpengaruh signifikan terhadap tingkat kemiskinan. Menurut Sukirno (2000), perkembangan pertumbuhan ekonomi adalah naiknya PDRB tanpa melihat dari besar kecilnya kenaikan yang terjadi. Selain itu, pembangunan ekonomi tidak hanya dengan berdasar pada pertumbuhan produk domestik regional bruto (PDRB) secara keseluruhan, tetapi juga perlu dilihat sudah berapa banyak distribusi pendapatan telah menyebar kepada masyarakat dan siapa sajakah yang telah menikmati hasil-hasilnya (Khabhibi, 2013). Terdapat alasan lain mengapa pertumbuhan ekonomi tidak memberikan pengaruh secara signifikan terhadap tingkat kemiskinan yaitu karena kondisi pertumbuhan ekonomi pada sepuluh tahun terakhir ini meningkat sehingga penduduk NTT terselamatkan dari masalah ekonomi.

Pendidikan yang dilihat dari rata-rata lama sekolah di Provinsi NTT selama tahun 2011-2017 diperoleh tidak berpengaruh signifikan terhadap tingkat kemiskinan. Berdasarkan argumen yang dikemukakan oleh Arsyad (1997), bahwa variabel pendidikan memiliki hubungan yang berkebalikan atas tingkat kemiskinan. Aspek pendidikan dinilai berperan penting untuk mengurangi tingkat kemiskinan dalam jangka panjang, baik formal maupun non formal, ataupun secara langsung atau tidak langsung (Sunarya \& Indrawati, 2018). Pendidikan bisa berperan secara langsung, yaitu melalui pelatihan golongan miskin dengan bekal keterampilan yang dibutuhkan untuk meningkatkan produktivitas. Pendidikan juga bisa berperan secara tidak langsung, yaitu melalui perbaikan produktivitas dan efisiensi secara umum. Tujuan akhir dari peran lama pendidikan secara langsung maupun tidak langssung itu pada gilirannya mampu meningkatkan jumlah pendapatan mereka.

Peningkatan pendidikan dalam hal ini diwakili oleh rata-rata sangat penting karena dengan meningkatknya pendidikan yang akan meningkatkan human capital, dan pada akhirnya akan meningkatkan produktivitas manusia demi membantu golongan miskin untuk keluar dari kemiskinan (Astuti, 2015). Alasan lainnya mengapa pendidikan tidak 
berpengaruh kepada tingkat kemiskinan di daerah NTT yaitu meski rata-rata penduduk NTT sebagian besar hanya kelulusan SMA dan SMK, tetapi persentase kelulusan UN di sekolah sekitar 78 persen bahkan banyak lima sekolah yang meraih hasil 100 persen kelulusan. Hal ini artinya pendidikan di NTT sudah lebih baik dibandingkan tahun-yahun sebelumnya, sehingga dapat dinyatakan pendidikan bukan faktor penyebab terjadinya kemiskinan. Meskipun hanya lulus jenjang SMA/SMK, mereka tetap bisa dapat bekerja walaupun hanya sebagai buruh biasa. Hal ini berkaitan dengan pengangguran, dimana terbukti bahwa tingkat pengangguran selama sepuluh tahun terakhir ini di Propinsi NTT semakin berkurang.

\section{SIMPULAN}

Hasil-hasil yang diperoleh dalam penelitian ini menunjukkan bahwa indeks pembangunan manusia terbukti memiliki pengaruh negatif dan signifikan terhadap tingkat kemiskinan; sementara variabel lama pendidikan terbuki berpengaruh positif dan signifikan terhadap tingkat kemiskinan. Di sisi lain, tingkat pengangguran terbukti memiliki pengaruh positif tetapi tidak signifikan terhadap tingkat kemiskinan; sementara pertumbuhan ekonomi berpengaruh negatif namun tidak signifikan terhadap tingkat kemiskinan. Lebih jauh, keempat variabel independen yang dicakup dalam penelitian ini terbukti memiliki pengaruh simultan yang signifikan terhadap tingkat kemiskinan.

Selain itu, hasil analisis atas koefisien determinasi menyatakan bahwa variabelvariabel independen yang digunakan dalam penelitian ini memiliki kemampuan menjelaskan yang relatif besar atas perubahanperubahan yang terjadi atas kemiskinan penduduk di Propinsi NTT.
Pemerintahan Provinsi NTT melalui sejumlah kabupaten dan kotanya berupaya untuk dapat meningkatkan kualitas hidup masyarakat setempat serta terpenuhinya kebeutuhan lainnya. Hal yang harus diperhatikan untuk keberlangsungan hidup agar masyarakat bisa lebih sejahtera, yaitu pentingnya untuk memberikan pelayanan pendidikan dan program-program lainnya guna memperbaiki pembangunan manusia. Artinya, jika pembangunan manusia membaik maka suatu daerah akan bisa mencapai pertumbuhan ekonomi yang baik juga sehingga dapat mengurangi kemiskinan.

Faktor kesehatan, pendidikan serta daya beli masyarakat dinilai juga perlu ditingkatkan oleh pemerintah. Pemerintah juga dapat memberikan pelayanan di sektor pendidikan serta memperbaiki infrastruktur sangat di perlukan juga di daerah NTT dan mengurangi korupsi, sehingga dana bantuan untuk daerah NTT dapat dialokasikan sesuai kebutuhan, khususnya bagi masyarakat miskin. Sehingga kualitas SDM lebih meningkat yang diharapkan dapat menurunkan jumlah penduduk miskin. Perhatian pemerintah tehadap sector kesehatan juga masih perlu ditingkatkan melalui program pelayanan kesehatan gratis, memperbanyak puskesmas khususnya pada masyarakat yang berada di daerah pedalaman yang sangat membutuhkan bantuan kesehatan.

\section{REFERENSI}

Aldino, M.P.G. 2018. Analisis Kemiskinan di Jawa Tengah. Skripsi. Yogyakarta: Fakultas Ekonomi dan Bisnis, Universitas Islam Indonesia.

Alhudhori, M. 2017. Pengaruh IPM, PDRB dan Jumlah Pengangguran terhadap Penduduk Miskin di Provinsi Jambi. Ekonomis: Journal of Economics and Business. 1(1): 113-124.

Amalia, F. 2012. Pengaruh Pendidikan, Pengangguran dan Inflasi terhadap Tingkat Kemiskinan di Kawasan Timur 
Indonesia (KTI) Periode 2001- 2010. Jurnal Ilmiah Econosains. 10(2): 158169.

Arsyad, L. 1997. Ekonomi Pembangunan. Yogyakarta: STIE YKPN.

Astuti, P.B. 2017. Efektifitas dan Pengaruh PNPN Mandiri Pedesaan Alokasi Dana Desa dan Jumlah Penduduk terhadap Jumlah Kepala Keluarga Miskin di Kabupaten Kebumen Tahun 2009-2011. Jurnal Fokus Bisnis. 12(3): 1-19.

Astuti, R.R. 2015. Analisis Pengaruh Jumlah Penduduk, Pertumbuhan Ekonomi, Pendidikan dan Kesehatan terhadap Jumlah Penduduk Miskin di Indonesia Tahun 2004-2012. Skripsi. Yogyakarta: Fakultas Ekonomi Universitas Negeri Yogyakarta.

Dewi, N., Yusuf, Y. \& Iyan, R.Y. 2017. Pengaruh Kemiskinan dan Pertumbuhan Ekonomi terhadap Indeks Pembangunan Manusia di Provinsi Riau. JOM Fekon. 4(1): 870-882.

Irawan, A.A. 2017. Dampak Ekonomi dan Sosial Aktivitas Tambang Batubara PT. Tanito Harum bagi Masyarakat di Kelurahan Loa Tebu Kecamatan Tenggarong. Jurnal Fisipol Universitas Mulawarman. 1(1): 46-56.

Jundi, M.A. 2014. Analisis Faktor yang Mempengaruhi Tingkat Kemiskinan Provinsi di Indonesia. Skripsi. Semarang: Fakultas Ekonomi dan Bisnis, Universitas Diponegoro.

Khabhibi, A. 2013. Analisis Faktor-Faktor yang Mempengaruhi Tingkat Kemiskinan (Studi Kasus 35 Kabupaten/Kota di Propinsi Jawa Tengah Tahun 2011). Skripsi. Surakarta: Fakultas Ekonomi Universitas Sebelas Maret.

Mankiw, N.G. 2006. Makro Ekonomi. Jakarta: Penerbit Erlangga.

Nailatussa'adah, A. 2019. Analisis Pengaruh Pertumbuhan Ekonomi, Tingkat Pendidikan, Pengangguran dan Jumlah Penduduk terhadap Kemiskinan di Karisidenan Pati Tahun 2011-2017. Skripsi. Surakarta: Fakultas Ekonomi dan Bisnis Universitas Muhammadiyah.
Nugroho, W. 2012. Analisis Pengaruh PDRB, Agrishare, Rata-Rata Lama Sekolah, dan Angka Melek Huruf, terhadap Jumlah Penduduk Miskin di Indonesia. Skripsi. Semarang: Fakultas Ekonomi dan Bisnis Universitas Diponegoro.

Nurwati, N. 2008, Kemiskinan: Model Pengukuran, Permasalahan dan Alternatif Kebijakan. Jurnal Kependudukan Padjajaran. 10(1): 1-11.

Pattimahu, T.V. 2016. Analisis Pengaruh Jumlah Penduduk dan Pengangguran terhadap Tingkat Kemiskinan di Maluku. Cita Ekonomika, Jurnal Ekonomi. 10(1): 40-48.

Prasetio, W. 2018. Determinasi Kemiskinan Penduduk di Pulau Sumatera. Skripsi. Lampung: Fakultas Ekonomi dan Bisnis. Universitas Lampung.

Risno. 2017. Pengaruh Domestik Regional Bruto dan Jumlah Penduduk terhadap Kemiskinan di Provinsi Sumatera Selatan. Skripsi. Palembang: Fakultas Ekonomi dan Bisnis. UIN Raden Fatah Palembang.

Saidy, E.N. \& Hidayah, N. 2018. Fenomena Kemiskinan di Kota Makassar dan Upaya Penanggulangannya Dalam Perspektif Islam. Laa Maisyir. 5(18): 43-59.

Sartika, C., Balaka, M.Y. \& Rumbia, W.A. 2016. Studi Faktor-Faktor Penyebab Kemiskinan Masyarakat Desa Lohia Kecamatan Lohia Kabupaten Muna. Jurnal Ekonomi UHO. 1(1): 106-118.

Siregar, H. \& Wahyuniarti, D. 2008. Dampak Pertumbuhan Ekonomi terhadap Penurunan Jumlah Penduduk Miskin. http://pse.litbang.deptan.go.id/ind/pdf files/PROS 2008 MAK3.pdf. Diakses tanggal 11 Januari 2019.

Sukirno, S. 2000. Pengantar Ekonomika Makro. Jakarta: PT RajaGrafindo Persada.

Sunarya, I.B. dan Indrawati, D. 2018. Analisis Pengaruh PDRB Per Kapita, Pendidikan, Kesehatan, Pengangguran dan Upah Minimum terhadap Tingkat Kemiskinan di Provinsi Jawa Tengah 
Tahun 2010-2015. Skripsi. Bandung: Fakultas Ekonomi dan Bisnis Universitas Padjadjaran.

Surayya, L. 2018. Analisis Pengaruh Pertumbuhan Ekonomi Tingkat Pengangguran dan Tingkat Pendidikan terhadap Kemiskinan di Jawa Tengah 2011-2015. Skripsi. Surakarta: Fakultas Ekonomi dan Bisnis Universitas Muhammadiyah Surakarta.

Suryandari, A.N. 2017. Pengaruh Pertumbuhan Ekonomi, Pendidikan dan Kesehatan terhadap Tingkat Kemiskinan di Provinsi Daerah Istimewa Yogyakarta Tahun 2004-2014. Skripsi. Yogyakarta: Universitas Negeri Yogyakarta.
Susanto, E., Rochaida, E. \& Ulfah, Y. 2017. Pengaruh Inflasi terhadap Pengangguran dan Kemiskinan. Inovasi. 13(1): 19-27.

Swaramarinda, D.R. 2014. Analisis Dampak Pengangguran terhadap Kemiskinan di DKI Jakarta. Jurnal Pendidikan Ekonomi dan Bisnis. 2(2): 63-70.

Tambunan, T. 2014. Perekonomian Indonesia. Edisi 11. Jakarta: Erlangga.

Yarlina, Y. 2012. Pengaruh Tingkat Pengangguran terhadap Tingkat Kemiskinan Kabupaten/Kota di Provinsi Kalimantan Barat. Jurnal Eksos. 8(3): 176-185.

Zuhdiyaty, N. \& Kaluge, D. 2017. Analisis Faktor-Faktor yang Mempengaruhi Kemiskinan di Indonesia selama Lima Tahun Terakhir. JIBEKA. 11(2): 27-31. 